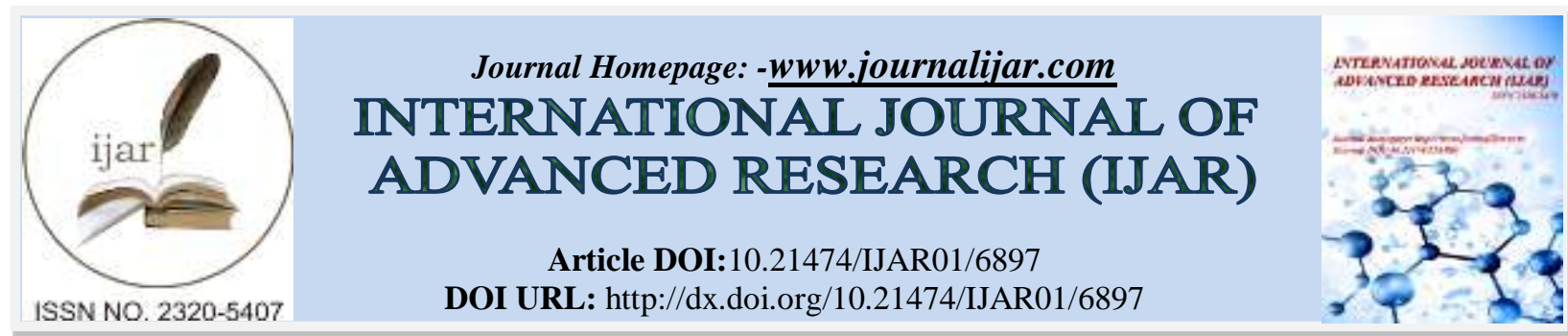

RESEARCH ARTICLE

\title{
AN ASSESSMENT OF THE KNOWLEDGE, ATTITUDES AND PRACTICE OF ADULT EDUCATION PRINCIPLES BY UNIVERSITY EXTENSION EDUCATION PART-TIME TUTORS IN LUSAKA DISTRICT OF ZAMBIA.
}

\author{
Michelo Haluyasa and Wanga, W. Chakanika.
}

University of Zambia, Zambia.

\section{Manuscript Info}

Manuscript History

Received: 09 February 2018

Final Accepted: 11 March 2018

Published: April 2018

\section{Abstract}

The problem for the study emerged from the fact that there was no evidence showing how part time-tutors practice the principles of adult education. It was also not known whether or not part time tutors were knowledgeable of the principles of adult education and what their attitudes towards these principles were. Thus, the purpose of this study was to establish tutors' knowledge, attitudes and practice of adult education principles in Lusaka District. The objectives were to: examine whether or not part- time tutors were knowledgeable of adult education principles; establish the attitudes of the part- time tutors towards adult education principles; and investigate whether or not part time tutors practice adult education principles in their teaching. This study adopted a mixed method design. The study sample was 111 which comprised 60 students who were selected using simple random sampling procedure, 50 tutors who were traced through snow ball sampling procedure and 1 Resident Lecturer who was selected using purposive sampling procedure.

Findings revealed that majority part- time tutors were not familiar with adult education principles in Lusaka District. For example, 28 (56\%) respondents were not familiar with adult education principles compared to $22(44 \%)$ respondents who were familiar with some of the principles. It was also established that part- time tutors' attitudes towards students were good as they embraced voluntary participation and learners' experience. Findings further revealed that tutors were not sure as to whether or not they practiced adult education principles and that they did not receive any form of training on how to teach adults or practice adult education principles.

It was thus recommended that the Resident Lecturer should see to it that all coordinators assigned to the centres were oriented in the principles of adult education; that the Resident Lecturer should assign coordinators who possess certificates in adult education to run the centres; that the Resident Lecturer should not just assume that adult education principles were practiced, instead she should frequently visit the centres and assess part- time tutors' knowledge, attitudes and practice of adult education principles; Part-time tutors appointed to teach in university extension education studies should be oriented in the principles of adult education; the University of Zambia Central 
Administration should allocates enough financial resources to university extension centres in Zambia; the University of Zambia through the Department of Adult Education and Extension Studies (DAEES) should find alternative ways of encouraging students to attend classes rather than registers because some students view them as an indirect way of forcing them to attend classes.

Copy Right, IJAR, 2018,. All rights reserved.

\section{Introduction:-}

University extension education in Zambia replicated its historical development in Britain in respect of its purpose and objectives. The origin of extension education in Britain was first recorded in the $19^{\text {th }}$ century. The first proponent of University extension education in Britain was a politician by the name of Lord Henry Brougham, an influential advocate of formal education for the poor and of mass adult education who founded the society for the diffusion of useful knowledge in 1826. It is important to note that during the industrial revolution, Britain did not only experience shortage of skilled human resource to operate machines in industries but was also faced with high levels of illiteracy among the poor. At that time, two social classes existed in Britain which were the Upper and the Lower classes. The lower class did not access quality or good education (Mukumbi, 2015).

The growth and success of extension work in Britain influenced the initiation of similar activity elsewhere and Zambia is no exception. The origin and development of University extension education in Zambia can be traced back to 1964 when the country gained her political independence from British rule. Prior to independence, Northern Rhodesia, which is currently known as Zambia, belonged to the Federation of Rhodesia and Nyasaland, which began in 1953 and ended in 1963 (Nduna, 2011).

During the Federal era, the mining industry was the only sector of Northern Rhodesia's economy which was developing. The Agricultural industry deteriorated because of preferential treatment and higher prices which were paid to white commercial farmers for maize and other products (Carmody, 2004). Alongside this background stood an educational system which was woefully inadequate to meet the challenges of the Post-colonial society. For instance, the few schools which were run by Christian Missionaries could not allow the enrolment of too many African pupils (Sandlane, 1989). As a consequence of the above factors, Zambia had only 100 University graduates and about 961 Cambridge school leavers against a population of 4 million people at independence (GRZ, 1966).

Due to the above hostile circumstances that existed during Zambia's attempt to attain self-rule, there was need for Zambia to have a University in order to produce highly skilled human resource. University extension education was at this time thought to be most appropriate to bring about development because its clientele were working adults. Due to this development, a Commission was appointed under the chairmanship of Sir John Lockwood who was the former vice chancellor of the University of London. The Lockwood Commission was therefore entrusted with the responsibility to counsel government on the prospects of establishing a University in Zambia. In November 1963, the Lockwood Commission recommended that, a University was to be constructed in Lusaka without undue delay (Lockwood Report, 1963). The Lockwood Commission also recommended that the University of Zambia must combine practical service to the nation at a critical time of its life, with the fulfilment of the historical purposes for the University as a seat of learning, a treasure-house of knowledge and a creative centre for research.

In addition to this, the Commission recommended that the University of Zambia should lower the illiteracy levels of the country in order to produce the required human capital and to lower its entry qualifications so as to serve the entire nation and not a diminutive cluster of undergraduates. It further recommended that the University of Zambia should make a provision for both the extension of its degree and diploma programmes to the people outside the University and to offer non-formal and non-credit programmes to people who had no opportunity to access higher education (Lockwood Report, 1963). This marked the birth of the Department of Extra-Mural Studies at the University of Zambia (Nduna, 2011).

In 1966, the University opened its doors to the public; the Department of Extra Mural Studies was also established. Cardinal principles which underlie the work of the Department were laid down by the University Senate. The duty of the Department was to: 
".... maintain the University links with the community, and recognize that the University has a contribution to make to society as a whole and not only to the small group of graduates and undergraduates on campus, and diffuse University knowledge and university ways of thought throughout the nation, and recognize that it is possible to stimulate objective and coherent thinking among mature men and women of varying levels of formal education (First Extra Mural Annual Report, 1966: 6).”

Since its inception, the Department of Adult Education and Extension Studies has been offering non-credit programmes to the community until the year 2002 when it received considerable demand for credit courses from the community. This demand was more prominent among school leavers whose justification for participating in University extension education was mainly to search for employment. On the other hand, University extension education non-credit diploma graduates developed a negative attitude towards University extension education after employers rejected their non-credit certificates (Phiri, 2013).The displeased members of the community, students and graduates mounted pressure on the University of Zambia to initiate University extension credit courses to the Zambian community. Currently, credit courses are offered alongside non-credit programmes in all University Extension Education at Provincial Centres in Zambia (Moonga and Luchembe, 2008).

Emanating from the above background, what was clear is the fact that from 2009, the University of Zambia has been offering credit-courses in its extension education programme, making it a bifurcated system as it carries both credit and non-credit courses. It was also known that the non-credit courses have been applied through public lectures conducted for a mixed target group; through Theatre for Development which has been used in reaching the grassroots level members of the society; through Seminars or Workshops which cater for a broader clientele; and through evening classes (Chakanika and Mtonga, 1995). Moreover, it was also clear that since 2009, the institution has been engaging tutors on a part-time basis to teach credit courses in extension education programme (Phiri, 2015). These tutors are holders of bachelors and some even masters' degrees from different fields of specialization appointed on a one year renewable contract by senate.

The system has produced a cohort of certificate and diploma holders in various fields. However, there was lack of information showing how part time-tutors engaged by the University of Zambia practiced the principles of adult education. It was also not known whether part -time tutors were knowledgeable of the principles of adult learning and what their attitudes towards these principles were. This implied that tutors' knowledge, attitudes and practice of adult education principles were not yet established even though a lot of students have been graduating.

Lindeman (1926) argues that in order for adult educators to select appropriate teaching techniques, they should have the knowledge of adult education principles and how to apply them in their teachings. The way adults learn differs from the way children learn. Therefore, for effective teaching to take place, the facilitators should have good knowledge of how adults learn. Similarly, Vella (2007) observed that having prior knowledge of adult education principles can help adult educators to develop and/or use instructional materials that are based on students' lives. The forgoing discussion confirms the fact that the knowledge on adult education principles can help educators to select appropriate and effective teaching techniques. Nevertheless, since 2009 when credit courses were infused in the University of Zambia (UNZA) extension education programme, it was not yet established as to whether or not parttime tutors were knowledgeable of adult education principles, what their attitudes were and as to whether or not they practiced the principles of adult education. The current study therefore, sought to assess the knowledge, attitudes and practices of adult education principles by University extension part- time tutors in Lusaka District.

\section{Statement of the problem:-}

University extension education in Zambia has been in existence since 1966 (Kelly, 1999). This education paradigm has improved from just providing non-credit courses into a bifurcated system embracing both credit and non credit courses since 2009. From 2009, the University of Zambia has been engaging tutors on a part-time basis and the system has produced a cohort of certificate and diploma holders in various fields. One undisputed fact however, is that University of Zambia (UNZA) extension education deals with adults and hence cannot exist without embracing the principles of adult education. Despite this notable relationship between the two disciplines, there is no evidence showing how part -time tutors practice the principles of adult education. It is also not known whether part-time tutors are knowledgeable of the principles of adult learning and what their attitudes towards these principles are. This study therefore, sought to assess the knowledge, attitudes and practice of adult education principles by University extension part-time tutors in Lusaka District. 


\section{Research objectives:-}

This study was guided by the following objectives:

1. To examine whether or not part- time tutors are knowledgeable of adult education principles;

2. To establish the attitudes of the part- time tutors towards adult education principles; And

3. To investigate whether or not part time tutors practice adult education principles in their teaching.

\section{Theoretical framework:-}

This study adopted Andragogy (adult learning theory) theory by Malcolm Knowles. According to Knowles (1980), Andragogy is defined as "the art and science of helping adults learn." This theory is viewed to be relevant to the study as it explains how adults learn. It also gives more insights on how adult educators should treat and teach adults.

\section{Methodology:- \\ Research Design:-}

This study adopted a mixed-method research design so as to allow the researcher to collect and analyse both qualitative and quantitative data. A mixed method design allowed the researcher to triangulate the study by using both qualitative and quantitative data collection methods. This connotation is supported by Cohen et al (1994) who intimate that the use of both qualitative and quantitative approaches in research enables the researcher to cross check research findings. It is envisaged that a combination of qualitative and quantitative research designs helps to explain fully the richness and complexity of a given phenomenon by studying it from more than one view point. Additionally, mixed method also employs both open and closed ended questions, both emerging and predetermined approaches, and both qualitative and quantitative data analysis (Caruth, 2013). The researcher decided to use mixed method design because it explains and interprets data; it complements the strength of a single design, overcomes the weakness of a single design and addresses a theoretical perspective at different levels.

\section{Universe Population:-}

A population is a group of individuals, objects or items from which samples are taken for measurement; for instance the population of students (Kasonde-Ng'andu, 2013). In the same vein, Phiri (2013) defines population as an entire group of persons or elements that have at least one thing in common. The above definitions are applicable to this study because the universe population meant a group of individuals with the same characteristics from which the sample was drawn. Therefore, the universe populations for this study encompassed all students, tutors and the resident lecturer from the University of Zambia Extension Education Programme in Lusaka District.

\section{Sample Size:-}

A sample is defined as a sub-set drawn from the universe population, whose findings can be generalized to the universe population. In the view of Kasonde-Ng'andu (2013), a sample is defined as a portion from the population. It refers to the number of participants selected from the universe to constitute a desired sample. Sampling is essentially a technical device used to choose, in an appropriate way, and following scientific criteria, a small and restricted set of objects, persons and events from which the actual information will be drawn in order to learn more about the whole population (Bless and Craig, 1995). Hence, this study consisted of 111 respondents divided as follows; 60 students, 50 tutors and 01 Resident Lecturer.

\section{Sampling Procedure:-}

Kasonde-Ng'andu (2013) defines sampling techniques as that part of the research plan that indicates how cases are to be selected for the study. It is the process a researcher uses to gather people, places or things for study. It is also the process of selecting a number of individuals or objects from a population such that the selected group contains elements representative of the characteristics found in the entire group (Orodho and Kombo, 2002).

In this study participants were selected as follows; the Resident Lecturer was selected using purposive sampling procedure. Parahoo (1997) describes purposive sampling as "a method of sampling where the researcher deliberately chooses who to include in the study based on their ability to provide necessary data". Purposive sampling allows, the researcher to purposely target a group of people believed to be reliable for the study. The strength of purposive sampling lies in selecting information rich cases for in- depth analysis related to the central issues being studied. Moreover, purposive sampling can be used with both qualitative and quantitative studies. This sampling procedure was viewed to be the best for the Resident Lecturer as he possessed a lot of information about University extension education. 
60 students who were second year students in the University extension education programme were picked using simple random sampling. Bhattacherjee (2012) cited by Zulu (2015), defines simple random sampling as a sampling technique in which all the units in a population are given an equal chance to be part of the sample. In order to conduct this sampling, it is imperative that the researcher has the complete sampling frame. Simple random sampling can occur with or without replacement. With replacement sampling the individuals or units that are selected to participate in the study, are returned in the pool from which the sample was drawn. Simple random sampling conducted without replacement yields estimates that are more precise (Loue, 1999).

Apart from the above, 50 tutors were selected using convenience sampling procedure. With regard to convenience sampling techniques, it is a qualitative research technique used by researchers involved in selecting individuals or groups that happen to be available and are willing to participate at the time of study (Henry, 1990). In the view of Cohen, et al (2007: 114), "Convenience sampling or, as it is sometimes called, accidental or opportunity sampling involves choosing the nearest individuals to serve as respondents and continuing that process until the required sample size has been obtained or those who happen to be available and accessible at the time. ..."

\section{Data Collection Procedure:-}

Data collection procedure is referred to as the gathering of information to serve or prove some facts. In research, data is collected to further a researcher's understanding of a puzzling issue (Kombo and Tromp, 2006). Therefore, to collect data for this study, the researcher obtained a clearance letter from the Directorate of Research and Graduate Studies at The University of Zambia. Afterwards, the researcher made an appointment with the Resident Lecturer of Lusaka Province in order to seek permission to interview her, and to distribute questionnaires to Part-time tutors and students in University extension education. The researcher personally conducted a separate interview with the Resident Lecturer and wrote down main points in the note book. The researcher jotted down the main points so that the information would later be copied. To collect data from 60 students and 50 tutors in University extension education, the researcher personally distributed the self- developed questionnaires. The researcher also personally collected all completed questionnaires from the students and part-time tutors at the point where the questionnaires were administered.

\section{Data Collection Instruments:-}

Kasonde-Ng'andu (2013) describes research instruments as the tools that the researcher uses in collecting the necessary data. In the perception of Parahoo (1997:52), a research instrument is “... a tool used to collect data. It is a tool designed to measure knowledge, attitudes and skills of research respondents". Consequently, this study used questionnaires and an interview guide in data collection. A questionnaire is a research instrument that gathers data over a large sample (Kombo and Tromp, 2006). In this study a questionnaire was administered on. On the other hand, an interview guide involves questions which are asked orally. According to Kasonde- Ng'andu (2013), an interview is a written list of questions or topics that need to be covered by the interview.

\section{Data Analysis:-}

According to Andrienko and Andrienko (2006), data analysis is defined as the process of computing various summaries and derived values from given data by studying and examining data in order to generate conclusions about the phenomenon under study using some analytic techniques. Therefore, the type of data analysis method used is profoundly dependent on the research design and the instruments used to collect data.

Since this study adopted a mixed method design in which both qualitative and quantitative data were collected, qualitative data were analysed through a thematic approach where data were tabulated, categorised and arranged into themes and sub themes. On the other hand, quantitative data was analysed manually and entered into windows eight excel where frequency tables and bar charts were generated. This type of analysis enabled the researcher to generate conclusions about the phenomenon under study by critically examining the frequencies of numerical data percentages.

\section{Presentation Of Findings:-}

What is the level of knowledge part- time tutors have regarding adult education principles? 
Bar chart 4.1:- Distribution of respondents by their views on principles of adult education they were familiar with.

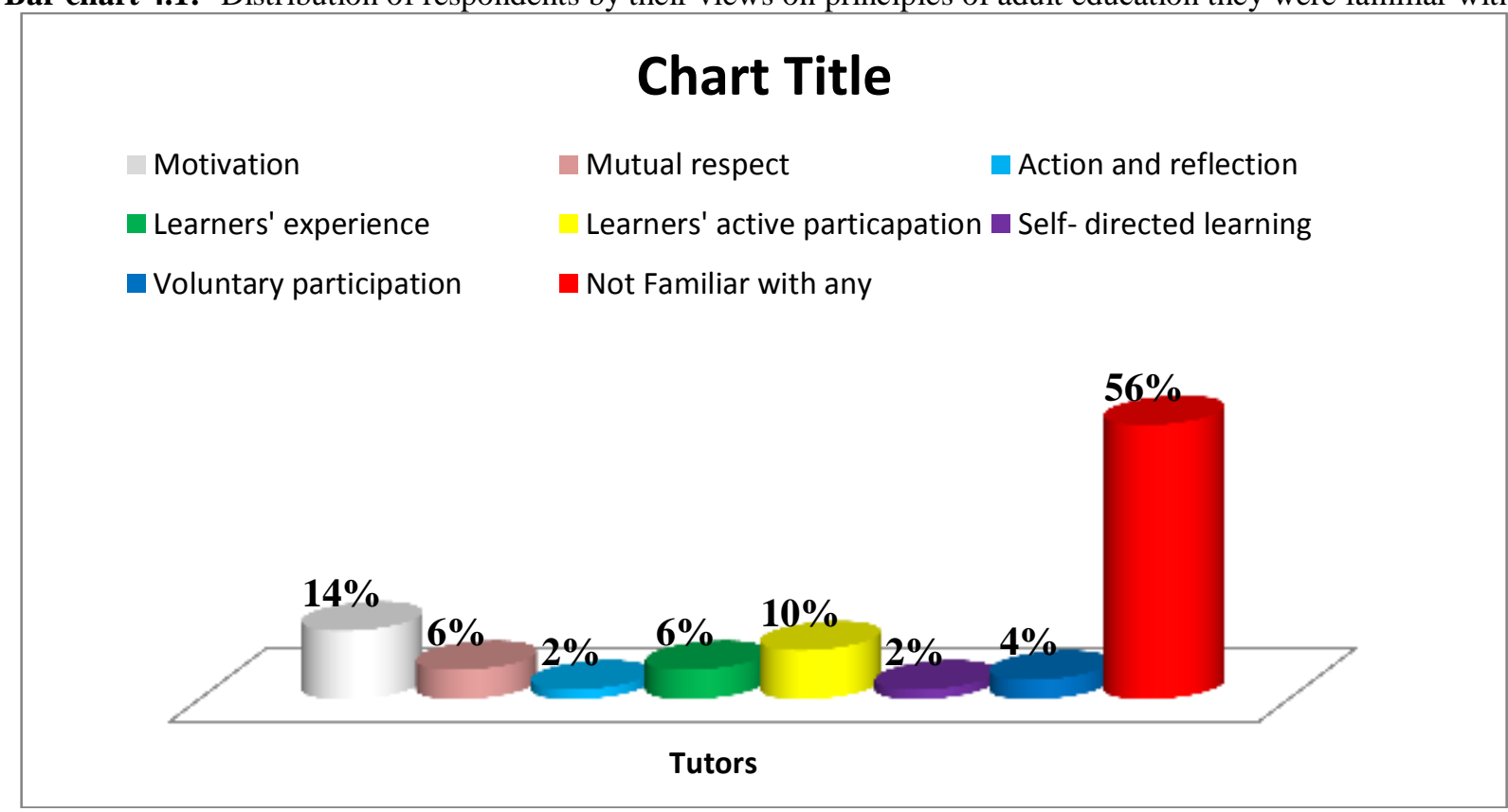

The findings in Bar chart 4.4 above show that 7 (14\%) respondents indicated that the only adult education principle they were familiar with was motivation. While $3(6 \%)$ indicated that the only adult education principle which was familiar to them was mutual respect. it was also noted that $1(2 \%)$ indicated that action and reflection was the only principle he or she was familiar with. Furthermore, findings established that $3(6 \%)$ respondents stated that they were familiar with learners' experience as a principle of adult education. Learners' active participation, self- directed learning and voluntary participation were also acknowledged by some respondents as principles of adult education and their percentage distribution was represented as $5(10 \%), 1(2 \%)$ and $2(4 \%)$ respectively. In addition, majority $(28=56 \%)$ respondents indicated that they were not familiar with the adult education principles. They had no idea concerning the adult education principles.

Findings from the Resident Lecturer:-

The Resident Lecturer had the following responses: some tutors are knowledgeable while others are not. She went on to say: in my own opinion the only tutors that are knowledgeable of the adult education principles are those who did adult education and those that had been teaching for a long period.

What is the attitude of part-time tutors towards adult education principles?

Table 4.1:-Distribution of respondents by their response to the kind of relationship that existed between students and their tutors

\begin{tabular}{|l|l|l|}
\hline Responses & Frequency & Percentage \\
\hline Very Good & 15 & $25 \%$ \\
\hline Good & 45 & $75 \%$ \\
\hline Bad & 0 & 0 \\
\hline Very Bad & 0 & 0 \\
\hline Total & $\mathbf{6 0}$ & $\mathbf{1 0 0 \%}$ \\
\hline
\end{tabular}

As indicated in Table 4.3 above, it was established that majority $(45=75 \%)$ respondents felt that the relationship between themselves and their tutors was good. On the other hand, $15(25 \%)$ respondents felt that the relationship between themselves and their tutors was very good. Findings further revealed that no student perceived the relationship between themselves and tutors to be bad or very bad.

Findings from the Resident Lecturer:-

The Resident Lecturer was asked whether or not part-time tutors knew how to handle adults, she said that: I think they know because I have not received complaints from students from the time I assumed office. Feedback on tutors' 
attitudes is usually obtained from students. If students are not treated well by the tutor, they are advised to report to the Resident Lecturer for action. She further added that: their attitudes are also good.

How do part- time tutors practice adult education principles in their teaching?

Bar chart 4.2:-Distribution of respondents on whether or not tutors practice adult education principles.

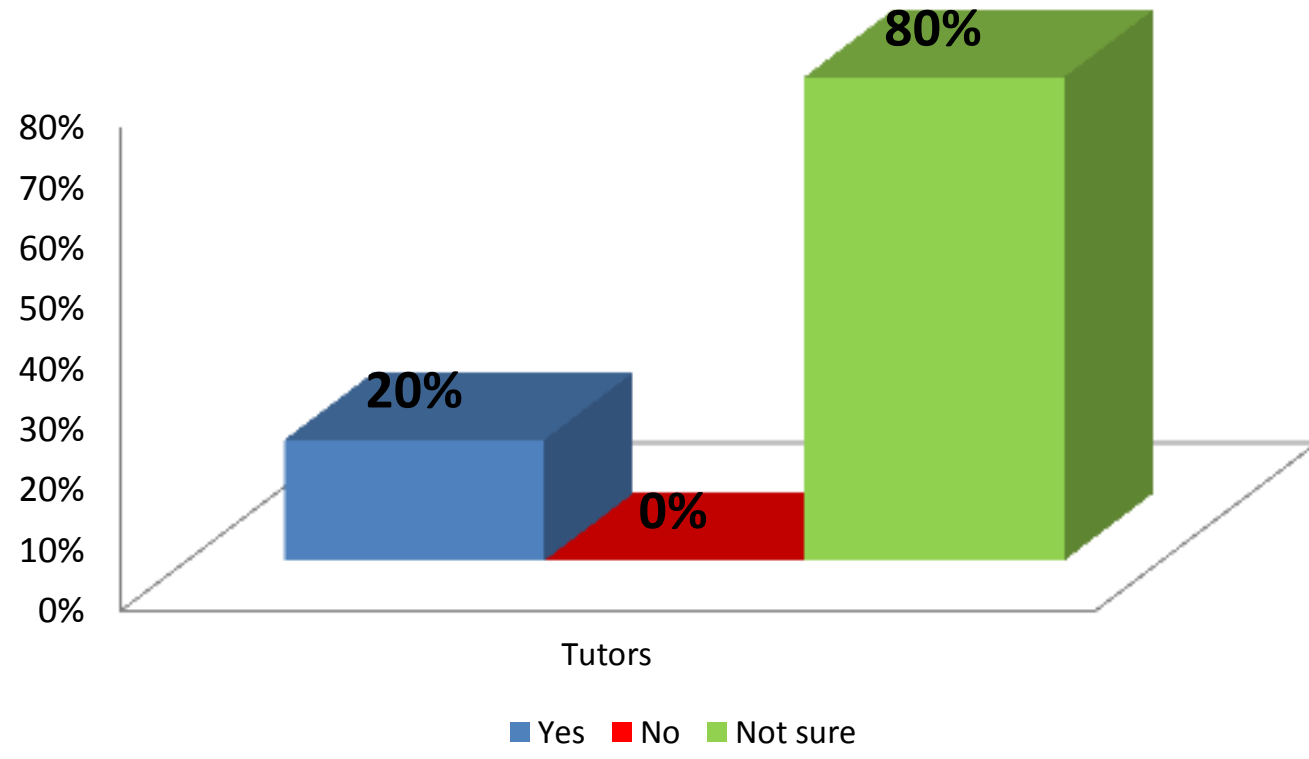

Findings in bar chart 4.7 above revealed that $10(20 \%)$ respondents practiced adult education principles while none of the respondents indicated that they did not practice the principles. Findings further revealed that majority $(40=$ $80 \%$ ) respondents revealed that they were not sure as to whether or not they used the principles. Respondents who were not sure justified that they did not do adult education so it was not easy for them to know and practice the adult education.

\section{Findings from the Resident Lecturer:-}

With regard to this research question, the Resident Lecturer had the following responses: Yes they practice. When asked if tutors were oriented or trained on how to teach adults, she remarked: I haven't been in this office for a long period and when I took over I was told that they are orientated. When asked who oriented them; responses were that Resident Lecturer and coordinators orient them upon appointment. When asked whether follow ups were made to verify how tutors' practice, her responses were: I don't follow up instead feedback is obtained from students on how they are handled by tutors. If students don't report that they are being mistreated, then it is assumed that the Adult education principles are practiced.

\section{Discussion of Findings:-}

To examine whether or not part- time tutors were knowledgeable of adult education principles:-

The study established that more than half of the respondents were not knowledgeable of adult education principles. Part- time tutors who expressed knowledge about the principles were less than those who were not knowledgeable. For example, from the sample of 50 part time tutors, $28(56 \%)$ respondents indicated that they were not familiar with adult education principles compared to $22(44 \%)$ respondents who indicated that they were familiar with some of the principles. Qualitative findings are also in agreement with the above findings.

The above is what Fry, Ketteridge and Marshall (2003:9) cited by Phiri (2015) meant when they pointed out that it is unfortunate, but true, that some academics teach students without having much formal knowledge of how students learn. Many lecturers know how they learn best, but do not necessarily consider how their students learn and if the way they teach is predicated on enabling learning to happen. On the other hand, the above findings contradict with Lindeman's (1926) thinking to the effect that in order for adult educators to select appropriate teaching techniques, 
they should have the knowledge of adult education principles and how to apply them in their teachings. The way adults learn differs from the way children learn. Therefore, for effective teaching to take place, the facilitators should have good knowledge of how adults learn.

Vella (2007) supports the above findings as well and contended that having prior knowledge of adult education principles can help adult educators to develop and/or use instructional materials that are based on students' lives.

\section{To establish the attitudes of part- time tutors towards adult education principles:-}

Findings revealed that a lot of students had a good relationship with their tutors. For example, majority $(45=75 \%)$ respondents felt that the relationship between themselves and their tutors was good. Furthermore, findings from parttime tutors also revealed that majority $(36=72 \%)$ respondents felt that their relationship with the students was good whereas $14(28 \%)$ respondents felt that the relationship between themselves and their students was very good. None of the tutors had either a bad or very bad relationship with their students. Additionally, qualitative findings obtained also revealed that part- time tutors' attitudes towards students were good. As one student elaborated: Tutors treat us well because they respect us; they don't shout us even if we give them wrong answers but instead encourage us to study hard. The above question was posed to determine whether or not principles such as mutual respect and learners' experience were adhered to.

Brookfield (1995) supports this finding as he states that, ...adult learning should be characterized by mutual respect among learners. To display disrespect to others, to denigrate their contributions, or to embarrass them publicly is likely to ensure withdrawal. This does not mean that criticism and reflection should be avoided in the discussions. It does mean that increasing the sense of self-worth of all participants should be uppermost in the minds of all concerned....

This finding further corresponds with Hippel and Tippelt (2009) cited by Mukumbi (2015) to the effect that, the quality of a tutor plays a central role in encouraging participation in extension programmes. Therefore, improving the competences and attitudes of Adult Educators contributes to an increase in participation.

The findings are also in line with the assumptions of andragogy theory as it entails that adult learning should be characterized by mutual respect among learners. Andragogy is of the view that adults are not like children hence, they deserve to be respected. As an adult educator, respect can be demonstrated to your students by taking interest, acknowledging the wealth of experiences that the student brings to the classroom, and by regarding them as colleagues who are equal in life experience. Encourage expression of ideas, reasoning and feedback at every opportunity (Lieb, 1991).

\section{To investigate whether or not part time tutors practice adult education principles in their teaching.-}

Findings from part- time tutors also revealed that majority $(40=80 \%)$ respondents were not sure whether or not they practiced adult education principles. Only $10(20 \%)$ respondents confirmed that they practiced adult education principles.

This confirms what Fry, Ketteridge and Marshall (2003:9) meant when they argued that:

. . Many lecturers know how they learn best, but do not necessarily consider how their students learn and if the way they teach is predicated on enabling learning to happen.

The above findings are in contrast to the principles of andragogy which emphasise that instruction for adults needs to focus more on the process and less on the content being taught. Strategies such as case studies, role play, simulations, and self-evaluation are most useful. Instructors adopt a role of facilitator or resource person rather than lecturer or grader. The theory further is not in accord with the findings because findings revealed that only the lecture technique was frequently used by part- time tutors. Additionally, the theory indicates that adults can only learn if they are ready to learn and that they learn because they want to solve a problem. In other words learning for adults should be problem centered (Knowles 1984: 12). It is clear that all this was not known by part-time tutors as they indicated that they were not sure as to whether or not they practiced adult education principles.

\section{Conclusion:-}

Based on the forgoing therefore, it can be interpreted that majority part- time tutors were not knowledgeable of adult education principles and that they were not sure whether or not they practiced adult education principles. 
Despite them not knowing the principles and that they were not sure whether or not they practiced. Findings from students indicated that part-time tutors actually did practice some of the adult education principles unknowingly and that their attitudes towards adult education principles were good.

\section{Recommendations:-}

Arising from the research findings, discussions and conclusion, the study recommends the following:

1. the Resident Lecturer should orient both tutors and coordinators on the principles of adult education;

2. the Resident Lecturer should assign coordinators who possess certificates in adult education to run the centres;

3. the Resident Lecturer should frequently visit the centres and assess part- time tutors' knowledge, attitudes and practice of adult education principles;

4. the University of Zambia Central Administration should allocate enough financial resources to university extension centres in Zambia;

5. the University of Zambia, through the Department of Adult Education should avoid registers because some students view registers as an indirect way of forcing them to attend classes.

\section{Summary of Chapter Six:-}

The main focus of this chapter was to conclude the study and to provide recommendations. This study was concluded using research objectives, and research questions, its purpose and theoretical framework. On the other hand recommendations emerged from research findings.

\section{Acknowledgements:-}

Special thanks go to my supervisor Wanga W. Chakanika for his patience, kindness, guidance, wisdom, help and fatherly advice he rendered to me during my study. He played a critical role in making me realize my full potential and for this i shall forever be grateful.

I extend my gratitude to the Resident Lecturer for Lusaka province who allowed me to collect data from UNZA Extension centres in Lusaka District. My heartfelt gratitude is further extended to Choolwe Muvwanga, Christopher Liswaniso, Conrad Munkombwe, Esnart Mwenya, Phanety Siamoongwa, Nyondwa Zulu and Davies Phiri, for being wonderful and helpful to me during my study. To all my course mates, I thank you for the moral support rendered to me during my study. Your encouragements motivated me to work extra hard and produce this dissertation.

I would also like to thank all the lecturers in the Department of Adult Education and Extension Studies for the help rendered during my study. Special thanks to Dr E. Mbozi, Dr G. Masaiti, Mr. A.L.H. Moonga for advice and assistance during my study.

I would also like to extend my appreciation to the management, tutors and students of the University of Zambia (UNZA) extension studies programme in Lusaka District for the cooperation that they rendered to me during the data collection process. Without these people, this work would not have been accomplished.

To my family, I thank you all for your encouragement and understanding whenever I was an able to attend to your problems due to academic pressure.

\section{References:-}

1. Andrienko, N. and Andrienko, G. (2006).Exploratory Analysis of Spatial and Temporal Data: A Systematic Approach. Berlin: Springer- Verlag.

2. Babbie, E. (2010). The Practice of Social Research. Boston: Cangage.

3. Bhattacherjee, A. (2012). Social Science Research: Principles Methods and Practices (2nd ed.). Florida: Creative Commons Attribution-Non Commercial- Share Alike.

4. Bless, C. and Craig, H.M. (1995). Fundamentals of social Research Methods: An African Perspective. Cape Town: Junta and Company.

5. Brookfield, S. (1995). "Adult learning an overview" in A. Tuinjman (Ed.) (1995). International Encyclopedia of Education. Oxford: Pergamon Press.

6. Carmody, B. (2004). The Evolution of Education in Zambia. Lusaka: Book world Publishers.

7. Caruth, G. D. (2013). "Demystifying mixed methods Research Designs: A Review of Literature."Mevlana International Journal of Education (MIJE), V. 3 (2): 112-122. 
8. Chakanika, W.W. andMtonga, H. (1995). "Constraints in University Work in Zambia: the Experience of two Resident tutors." International Journal of University Adult education, 24(1): 1-9.

9. Cohen, C. and Manion, L. (1994). Research methods in education (4th edition).

10. London and New York: Routledge.

11. Cohen, C., Manion, L., and Morrison, K. (2007). Research methods in education (sixth edition). New York: Routledge.

12. Fry, H., Ketteridge, S. and Marshall, M. (2003). Understanding student learning. In H. Fry, S.Ketteridge, and M., Marshall, (eds) (2003). A Handbook for Teaching \& Learning in Higher Education Second Edition (2nd Edition). London: Kogan Page Limited, pp. 9-25.

13. GRZ Report.(1966). Ministry of Education Annual Report. Lusaka: Government printer.

14. Henry, G. T. (1990). Practical Sampling. Vol. 21. London: Sage Publications.

15. Hippel, V. and Tippelt, R. (2009). "The Role of Adult Educators towards Potential Participants."European Journal of Research on education and Learning of adults, 1(1-2): 33-51.

16. Kasonde-Ng'andu. S. (2013). Writing a research proposal in education. Lusaka: UNZA Press.

17. Kelly, M.J. (1999). Origins and Development of Education in Zambia. Lusaka: Image publishers Limited.

18. Kelly, T. (1970). .A History of Adult education in Great Britain. Liverpool: Liverpool University Press.

19. Knowles, M. S., Holton, F. and Swanson, R. A. (1998).The Adult Learner. New York:Gulf Publishing Company.

20. Knowles, M. (1989). The making of an adult educator: An autobiographical journey (Ed.). San Francisco, CA: Jossey-Bass.

21. Knowles, M.S. (1980). The modern practice of adult Education.From Pedagogy to Andragogy. Pollett: Chicago.

22. Kombo D. K. and Tromp. D. L .A. (2006). Proposal and Thesis Writing: An introduction. Nairobi: Paulines Publications Africa.

23. Lieb, S. (1991). Adult learning principles. Retrieved from http://www.honolulu.comAccessed on $22^{\text {nd }}$ May, 2015 at 12 hrs.

24. Lindeman, E. (1926). The Meaning of Adult Education. Montreal: Harvest House.

25. Lockwood Report. (1963). Report on the Development of a University in Northern Rhodesia. Lusaka: Government Printer.

26. Loue, S. (1999). Gender, Ethnicity and Health Research. New York: Taylor \& Francis.

27. Luchembe, M. (2006).Equity and Access to University Extension Education through Adult Education and extension Studies in Livingstone Center in Zambia. Lusaka:Paper presented to Masters Students in Livingstone. Unpublished.

28. Moonga, A.H.L. and Luchembe, M. (2008).The Historical Development of the Department of adult Education and Extension Studies at the University of Zambia. Lusaka: UNZA. Department of adult Education

29. Mukumbi, L. (2015). An investigation of challenges inhibiting the community from participation in University Extension Education Credit Programmes in Mongu District of Zambia. Lusaka: University of Zambia. (Published Masters Dissertation).

30. Nduna, M. (2011).Challenges encountered by the University of Zambia in the implementation of University Extension Education. A case of North Western Province. (Masters Dissertation). Retrieved from http//: www.unza. Accessed on 12 October, 2014 at $15 \mathrm{hrs}$.

31. Orodho, A. J. and Kombo, D. K. (2002). Research Methods. Nairobi: Kenyata University institute of open learning.

32. Parahoo, A.K. (1997). Nursingresearch: Principles, processes \& issues. London: Macmillan Press.

33. Phiri, D. (2015).Students' perceptions of teaching techniques used by tutors in credit based courses of the University of Zambia extension programme in Lusaka District. Lusaka: University of Zambia. (Published Masters Dissertation).

34. Phiri, L. (2013). A study of University Extension Education in Zambia and the challenges faced in realizing its initial mission. A case of Lusaka and Central Provinces. (Unpublished Masters Dissertation).

35. Sandlane, M. (1989).Education System in Zambia since Independence (Masters Dissertation). Pretoria: Potchefstroom University.

36. Vella, J. (2007). “Quantum Learning: Teaching as Dialogue.”In Jovita M. Ross-Gordon (Ed.) (2007).Contemporary Viewpoints on Teaching Adults Effectively (pp. 73-83). San Francisco: Jossey-Bass.

37. Zulu, N. (2015). An Analysis of the Implementation Process of the Community-based Therapeutic Care Programme in Lusaka District. Lusaka: University of Zambia. (Published Masters Dissertation). 